\title{
The molecular basis of copper and iron interactions
}

\author{
Paul Sharp \\ Centre for Nutrition and Food Safety, School of Biomedical and Molecular Sciences, \\ University of Surrey, Guildford GU2 7XH, UK
}

\begin{abstract}
The intimate relationship between $\mathrm{Fe}$ and $\mathrm{Cu}$ in human nutrition has been recognised for many years. The best-characterised link is provided by caeruloplasmin, a multiCu-binding protein that acts as a serum ferrioxidase and is essential for the mobilisation of Fe from storage tissues. Decreased $\mathrm{Cu}$ status has been shown to reduce holo-caeruloplasmin production and impair ferrioxidase activity, leading, in a number of cases, to decreased tissue Fe release and the generation of anaemia that is responsive to dietary supplementation with $\mathrm{Cu}$ but not Fe. Dietary $\mathrm{Fe}$ absorption also requires the presence of a multiCu ferrioxidase. Hephaestin, a caeruloplasmin homologue, works in concert with the IREG1 transporter to permit Fe efflux from enterocytes for loading onto transferrin. The essential role of hephaestin in this process has been recognised from studies in the sex-linked anaemic (sla) mouse, in which Fe efflux is markedly impaired as a result of a mutation in the hephaestin gene that results in a truncated and non-functional version of the protein. There is emerging evidence that a number of other components of the intestinal $\mathrm{Fe}$ transport pathway are also $\mathrm{Cu}$ sensitive. Divalent metal transporter 1 (DMT1), the Fe transporter located at the apical membrane of enterocytes, is also a physiologically-relevant $\mathrm{Cu}$ transporter, suggesting that these two metals may compete with each other for uptake into the duodenal enterocytes. Furthermore, expression of both DMT1 and the basolateral Fe-efflux transporter IREG1 can be regulated by $\mathrm{Cu}$, suggesting that the $\mathrm{Fe}-\mathrm{Cu}$ relationship may be more complex than first thought.
\end{abstract}

Cu: Fe: Anaemia: Caeruloplasmin: DMT1

Copper status and body iron metabolism

The intimate relationship between $\mathrm{Cu}$ and $\mathrm{Fe}$ metabolism has been recognised for many years. In fact, $\mathrm{Cu}$ was identified as an 'anti-anaemic' factor as far back as 1928, when studies demonstrated that $\mathrm{Cu}$ could facilitate $\mathrm{Hb}$ formation (Hart et al. 1928). Indeed, the $\mathrm{Cu}-\mathrm{Fe}$ connection had been acknowledged for at least 100 years previous to this finding (for an extensive review, see Fox, 2003), but it is only relatively recently that the molecular basis for the biological interactions between these two metals has begun to be understood. The discovery of caeruloplasmin, the $\mathrm{Cu}$-dependent ferrioxidase, formed the initial bridge between $\mathrm{Fe}$ utilisation and $\mathrm{Cu}$ status. However, in recent years it has become apparent that $\mathrm{Cu}-\mathrm{Fe}$ interactions occur at the dietary and intestinal level. The molecular mechanisms underlying these interactions suggest that the $\mathrm{Cu}-$ Fe relationship may be more complex than it was first thought.

\section{Iron utilisation}

Body Fe content is $3-5 \mathrm{~g}$ (approximately $50 \mathrm{mg} / \mathrm{kg}$ body weight), of which approximately $70 \%$ is present in the circulating erythrocytes, $20 \%$ is stored as ferritin and haemosiderin in the liver, $5 \%$ is incorporated into myoglobin in muscle and $5 \%$ is bound or utilised by various enzymes (e.g. the cytochromes). Fe delivered to the tissues for metabolic utilisation or storage is carried in the circulation by transferrin, which binds to specific receptors on the cell surface allowing transferrin-bound $\mathrm{Fe}$ to be internalised via endocytosis. In the erythroid precursor newly-acquired $\mathrm{Fe}$ is delivered to the mitochondria for incorporation into haem, whereas in the liver $\mathrm{Fe}$ is directed for long-term storage in the cytosolic protein ferritin (for review, see Andrews, 1999, 2000).

The majority of metabolic Fe turnover in the body is accounted for by the continual synthesis and destruction of erythrocytes. The typical lifespan of an erythrocyte is

\footnotetext{
Abbreviations: Ctr, Cu transporter 1; DMT1, divalent metal transporter; IRE, Fe-responsive element; sla, sex-linked anaemia Corresponding author: Dr Paul Sharp, fax +44 1483 576978, email p.sharp@surrey.ac.uk
} 
$120 \mathrm{~d}$. After this time period, senescent erythrocytes are engulfed by cells of the reticulo-endothelial system (a combination of splenic macrophages and the Kupffer cells in the liver) and the $\mathrm{Fe}$ contained within $\mathrm{Hb}$ is recovered by the action of haem oxygenase. This liberated Fe can be either re-utilised for new erythrocyte production or can be delivered to the liver for long-term storage. From the total body load of $3-5 \mathrm{~g}$ only approximately $1 \mathrm{mg} \mathrm{Fe} / \mathrm{d}$ is lost through blood loss, desquamation of cells lining the gastrointestinal and urinary tracts, and skin (there are no defined excretory mechanisms for the disposal of excess body Fe). Thus, to maintain normal homeostatic Fe balance dietary Fe absorption must match endogenous Fe losses.

\section{Copper utilisation}

$\mathrm{Cu}$ released from the enterocyte travels in the portal blood, bound mainly to albumin and histidine, to the liver. Newly-acquired $\mathrm{Cu}$ is rapidly targetted towards a number of $\mathrm{Cu}$-dependent enzymes through the action of several intracellular chaperone proteins (for review, see Puig \& Thiele, 2002). Three of these chaperones have been well characterised and are known to distribute $\mathrm{Cu}$ to distinct cellular compartments. $\mathrm{Cu}$ chaperone for superoxide dismutase 1 delivers $\mathrm{Cu}$ for incorporation into the cytoplasmic $\mathrm{Cu}-\mathrm{Zn}$-dependent superoxide dismutase, an essential component of the cellular antioxidant protection network. Cyclooxygenase 17 transports $\mathrm{Cu}$ specifically to the mitochondria for insertion into the integral membrane enzyme cytochrome c oxidase. Human ATX1 homologue facilitates the movement of $\mathrm{Cu}$ into the secretory transgolgi network, where it can bind to the $\mathrm{Cu}$-transporting ATPases (ATP7A and ATP7B, the proteins mutated in Menkes disease and Wilson disease respectively), or can be incorporated into a number of other cupro-proteins, including the blood clotting factors V and VIII, tyrosinase and lysyl oxidase. In the liver a major proportion of the 'new' $\mathrm{Cu}$ is loaded onto caeruloplasmin (via a human ATX1 homologue/ATP7B-dependent process) before its release into the systemic circulation. Interestingly, while caeruloplasminbound $\mathrm{Cu}$ accounts for approximately $95 \%$ of the total serum $\mathrm{Cu}$, it appears that caeruloplasmin is not the $\mathrm{Cu}$ transport protein (in the same way that transferrin transports $\mathrm{Fe}$ ) employed for delivery of $\mathrm{Cu}$ to the tissues for metabolic purposes, since acaeruloplasminaemic patients (who have low levels or the absence of serum caeruloplasmin) have a normal tissue $\mathrm{Cu}$ content (Miyajima et al. 1987; Harris et al. 1998).

Unlike $\mathrm{Fe}$, there is no physiological store of $\mathrm{Cu}$ and body levels are therefore maintained by balancing dietary absorption, distribution and utilisation, with biliary excretion of excess $\mathrm{Cu}$. The liver is the main organ involved in the redistribution of $\mathrm{Cu}$ to various tissues for incorporation into the cupro-proteins and enzymes. In addition, the liver also controls the excretion of excess $\mathrm{Cu}$ into the bile. In Wilson disease, patients accumulate $\mathrm{Cu}$ within the liver and also exhibit an increase in the formation of apo-caeruloplasmin (i.e. caeruloplasmin lacking $\mathrm{Cu}$ ). Thus, the pathology of this disease illustrates the central role of the normal Wilson ATPase (ATP7B) in regulating body $\mathrm{Cu}$ metabolism, delivering $\mathrm{Cu}$ to caeruloplasmin so that it can perform its essential metabolic function (see p. 565) and targetting excess $\mathrm{Cu}$ to the biliary canalicular membrane for expulsion from the body in the bile (Mercer, 2001).

\section{The role of caeruloplasmin in iron metabolism}

Anaemias resulting from $\mathrm{Cu}$ or $\mathrm{Fe}$ deficiency display remarkably similar haematological features (Smith \& Medlicott, 1944; Cartwright et al. 1956), leading to the suggestion that a common pathway exists in the aetiology of these diseases. At an early stage it was suggested that the common factor in disease progression is a $\mathrm{Cu}$-dependent catalytic process. The search for $\mathrm{Cu}$-stimulated enzymic activity in serum has ultimately led to the isolation of a multiCu-binding protein with serum oxidase activity termed caeruloplasmin (Holmberg \& Laurell, 1948). Caeruloplasmin has subsequently been shown to act as a ferrioxidase, converting $\mathrm{Fe}^{2+}$ to $\mathrm{Fe}^{3+}$ (Curzon \& O'Reilly, 1960), and to increase the rate of loading of $\mathrm{Fe}$ onto transferrin (Osaki et al. 1966). Furthermore, the addition of caeruloplasmin (and apo-transferrin) to perfused liver preparations markedly stimulates $\mathrm{Fe}$ efflux, suggesting that caeruloplasmin is a crucial factor for the mobilisation of $\mathrm{Fe}$ from the body stores for its metabolic utilisation (Osaki \& Johnson, 1969). More recently, the key role of caeruloplasmin in Fe metabolism has been confirmed in studies on human patients and mice displaying disrupted caeruloplasmin production. Acaeruloplasminaemia is an autosomal recessive disorder that results in imbalances in body Fe metabolism, with symptoms that include high serum ferritin (indicative of high tissue Fe levels) and mild anaemia (Miyajima et al. 1987). The lack of caeruloplasmin as the cause of these symptoms has been confirmed in a knock-out mouse model of the human disease (Harris et al. 1999). Interestingly, infusion of caeruloplasmin into knock-out mice induces the release of Fe from the storage tissues.

It appears that this link between $\mathrm{Cu}$ and $\mathrm{Fe}$ is not limited to man, but is also evident in lower eukaryotic species. Genetic studies of Fe metabolism in the yeast Saccharomyces cerevisiae have shown that the $\mathrm{Cu}$-binding protein Fet3, which has sequence homology to caeruloplasmin, is required for high-affinity $\mathrm{Fe}$ uptake (Askwith et al. 1994; Dancis et al. 1994). Like caeruloplasmin, Fet3 has ferrioxidase activity, suggesting that oxidation and reduction of Fe are crucial to its movement across biological membranes.

\section{Diet-gene interactions: regulation of intestinal iron and copper absorption}

There is good evidence for a role for $\mathrm{Cu}$ in intestinal $\mathrm{Fe}$ absorption (Fig. 1). Studies in Cu-deficient animals have revealed that while uptake of $\mathrm{Fe}$ appears normal, efflux from the enterocytes is impaired (Lee et al. 1968). This decrease in the ability of the intestinal epithelium to release $\mathrm{Fe}$ acquired from the diet is not linked to the reduced ferrioxidase activity of caeruloplasmin associated with $\mathrm{Cu}$ deficiency, since Fe transport is not influenced by the addition of caeruloplasmin to intestinal preparations from $\mathrm{Cu}$-deficient rats (Coppen \& Davies, 1988). Furthermore, 


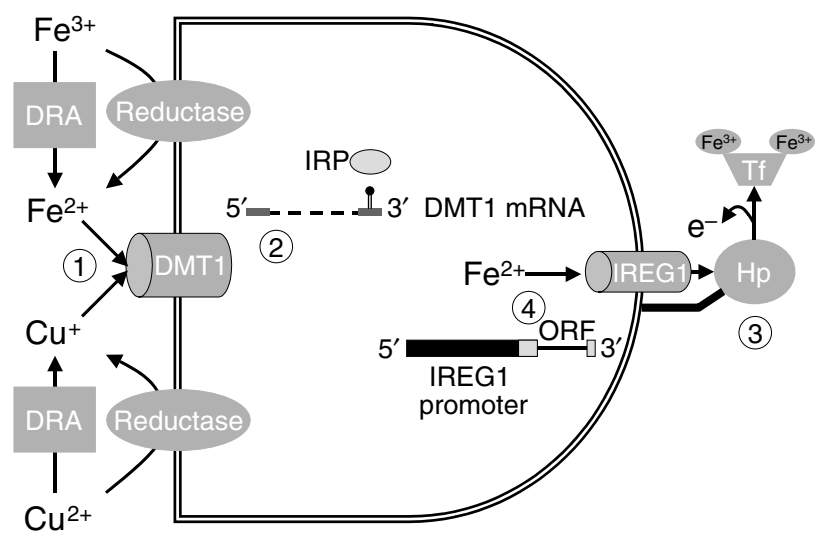

Fig. 1. Copper-iron interactions in the intestine. There are several potential mechanisms by which copper can alter the intestinal absorption of iron. (1) Recent data suggest that copper and iron compete for uptake into duodenal enterocytes via divalent metal transporter (DMT1). (2) Copper specifically regulates the expression of the iron-responsive element (IRE)-containing isoform of DMT1, possibly by modulating the RNA-binding activity of cytosolic iron regulatory protein (IRP). (3) Efflux of iron out of enterocytes is dependent on the presence of hephaestin, a caeruloplasmin homologue that acts as a multicopper ferrioxidase to facilitate the loading of iron onto transferrin. (4) Copper exposure increases the RNA and protein expression of the efflux transporter IREG1 with a concomitant increase in iron export from the cell. IREG1 regulation may occur at the level of the IREG1 promoter through interactions with an as yet uncharacterised copper-dependent transcription factor. Tf, transferrin; $\mathrm{Hp}$, hephaestin; DRA, dietary reducing agents; ORF, open reading frame.

no impairment of intestinal $\mathrm{Fe}$ transport is evident in caeruloplasmin knock-out mice (Harris et al. 1999).

\section{Mechanisms involved in dietary iron absorption}

Most Western diets contain a mixture of haem-Fe (found exclusively in animal tissues) and non-haem-Fe (found extensively in cereals and vegetables, but also in meat). Haem-Fe accounts for approximately $5-10 \%$ of the daily $\mathrm{Fe}$ intake in industrialised countries (Hallberg, 1981), whereas in vegetarian diets and in developing countries the haem-Fe intake is negligible. The main form of $\mathrm{Fe}$ in all diets is non-haem-Fe. Both haem- and non-haem-Fe are absorbed in the duodenum (the proximal region of the small intestine), through independent mechanisms. The processes involved in the uptake of haem are not clearly understood, but it is thought to be absorbed intact through an uncharacterised membrane transporter. Inside the enterocyte the $\mathrm{Fe}$ contained with the haem-porphyrin ring is excised by the action of haem oxygenase and it enters a common pool along with the non-haem-Fe.

Dietary non-haem-Fe is largely present in its less soluble and non-absorbable $\mathrm{Fe}^{3+}$ form and must therefore be reduced to $\mathrm{Fe}^{2+}$ before it becomes bioavailable. This reduction is achieved by the actions of both the dietary reducing agents (e.g. ascorbic acid) and the gut's endogenous reducing activity in the form of a recently-characterised ferric reductase duodenal cytochrome $b$ that resides on the apical membrane of duodenal enterocytes (McKie et al. 2001). $\mathrm{Fe}^{2+}$ generated by these reducing mechanisms can be transported into the cell by divalent metal transporter 1 (DMT1; Fleming et al. 1997; Gunshin et al. 1997), which is also present on the luminal membrane of duodenal enterocytes (Trinder et al. 2000). Uptake of $\mathrm{Fe}^{2+}$ by this transporter is driven by an inwardly-directed $\mathrm{H}^{+}$gradient (Gunshin et al. 1997; Tandy et al. 2000).

At this stage there are two possible fates for the absorbed dietary $\mathrm{Fe}$. If the body stores are adequate, $\mathrm{Fe}$ can be re-oxidised to $\mathrm{Fe}^{3+}$ and stored in the enterocytes as ferritin. Fe stored as ferritin is lost into the intestinal lumen when the enterocytes are sloughed off at the villus tip and may exit the body in the faeces. If there is a metabolic requirement for $\mathrm{Fe}$, it will enter a labile intracellular pool and be processed for transport out of the cell via a basolateral membrane export protein known variably as IREG1, ferroportin 1 or MTP1 (Abboud \& Haile, 2000; Donovan et al. 2000; McKie et al. 2000). $\mathrm{Fe}^{2+}$ leaving the enterocyte is immediately oxidised to $\mathrm{Fe}^{3+}$ by a ferrioxidase, hephaestin (Vulpe et al. 1999), and loaded onto transferrin for onward transport in the blood. Each transferrin molecule has the capacity to carry two $\mathrm{Fe}^{3+}$.

\section{Mechanisms involved in dietary copper absorption}

The human diet is thought to provide between 0.6 and $1.6 \mathrm{mg} \mathrm{Cu} / \mathrm{d}$, most of which is highly bioavailable $(\leq 70 \%$ is absorbed; Linder \& Hazegh-Azam, 1996). Dietary $\mathrm{Cu}$ is thought to be largely present as $\mathrm{Cu}^{2+}$. However, $\mathrm{Cu}$ is a redox metal that can rapidly change its oxidation state between +1 and +2 , and the reducing environment of the small intestinal lumen, together with endogenous copper reductase activity (Knopfel \& Solioz, 2002) on the apical surface of enterocytes, favours the existence of the $\mathrm{Cu}^{+}$ state. Interestingly, recent data have confirmed that $\mathrm{Cu}^{+}$is likely to be the species transported (Arredondo et al. 2003; Tennant et al. 2004). The nature of the $\mathrm{Cu}$ uptake pathway is still open to debate, but two candidate transporters exist in enterocytes, human $\mathrm{Cu}$ transporter 1 ( $\mathrm{Ctr} 1$; homologous to a family of yeast $\mathrm{Cu}$ transporters) and DMT1 (for review, see Sharp, 2003).

Absorbed $\mathrm{Cu}$ is immediately bound by a number of intracellular chaperones that direct $\mathrm{Cu}$ to specific cellular sites. In order for $\mathrm{Cu}$ to be released from enterocytes one of these chaperones, human ATX1 homologue, delivers $\mathrm{Cu}$ to the transgolgi network where it is loaded onto the Menkes ATPase (ATP7A protein). Cu-loaded Menkes ATPase translocates to the basolateral membrane of the enterocyte, releasing its $\mathrm{Cu}$ into the portal circulation where it is bound by histidine and albumin for delivery to the liver (Peña et al. 1999).

\section{The role of hephaestin in intestinal iron efflux}

The understanding of the link between intestinal $\mathrm{Fe}$ absorption and $\mathrm{Cu}$ status has been greatly enhanced by studies carried out in sex-linked anaemic (sla) mice. The sla phenotype is characterised by normal Fe absorption from the diet but defective transfer of $\mathrm{Fe}$ into the plasma. The chromosomal region containing the sla locus has 
subsequently been mapped (Anderson et al. 1998) and a candidate gene identified that is mutated in the sla mice. The gene encodes the protein hephaestin (Vulpe et al. 1999), a caeruloplasmin homologue that is widely expressed in intestinal tissue (Vulpe et al. 1999; Frazer et al. 2001; Rolfs et al. 2002). Recent studies have revealed that hephaestin exhibits marked ferrioxidase activity (Attieh et al. 2002) and that the mutation present in the sla mice would lead to protein misfolding and reduced ferrioxidase activity (Syed et al. 2002). It is unclear whether this ferrioxidase activity represents the main or the only mode of action of hephaestin in modulating Fe absorption. The initial predictions were that hephaestin would interact with IREG1 at the basolateral membrane to oxidise Fe, leaving the enterocytes for loading onto transferrin. However, recent immunohistochemical studies have cast some doubt on this hypothesis, demonstrating that hephaestin is localised largely within intracellular structures (Frazer et al. 2001).

\section{Copper-dependent regulation of intestinal metal transporter expression}

Emerging evidence suggests that hephaestin is not the only level at which intestinal $\mathrm{Fe}$ absorption can be regulated by $\mathrm{Cu}$ status. In $\mathrm{Cu}$-deficient rats there is a decrease in ferritin protein levels in enterocytes that leads to a reduced mucosal non-haem-Fe content (Thomas \& Oates, 2003). In addition, in Caco-2 cells, a well-established model of polarised intestinal epithelial cells, induction of $\mathrm{Cu}$ deficiency stimulates Fe uptake across the apical membrane (Zerounian \& Linder, 2002). This finding is in contrast to those of previous animal studies, which show no effect of $\mathrm{Cu}$ deficiency on the uptake step in $\mathrm{Fe}$ absorption (Lee et al. 1968). Interestingly, when Fe deficiency is induced in Caco-2 cells $\mathrm{Cu}$ uptake is increased (Linder et al. 2003) and, furthermore, when these cells are exposed to high $\mathrm{Cu}$ levels $\mathrm{Fe}$ uptake is markedly decreased (Tennant et al. 2002), suggesting that the absorption of these two metals may be closely related. Subsequent studies have shown that there is direct competition between $\mathrm{Cu}$ and $\mathrm{Fe}$ for uptake across the apical membrane (Tandy et al. 2000; Tennant et al. 2002; Arredondo et al. 2003). From the evidence available, therefore, it seems reasonable to suggest that dietary $\mathrm{Cu}$ and $\mathrm{Fe}$ utilise a common uptake pathway to enter intestinal epithelial cells. However, the nature of this common uptake mechanism is the subject of some debate. Two possible $\mathrm{Cu}$ transport mechanisms have been identified in intestinal cells, human Ctr1 (Lee et al. 2000) and DMT1 (Gunshin et al. 1997), but the relative roles of these two transport proteins in overall $\mathrm{Cu}$ transport are unclear. $\mathrm{Cu}$ absorption and excretion are tightly regulated to maintain a relatively constant body $\mathrm{Cu}$ content (Turnlund et al. 1989, 1998). In light of these findings a number of research groups have studied the effects of $\mathrm{Cu}$ loading or deficiency on the expression of Ctr1 and DMT1 in various model systems.

Human $\mathrm{Ctr} 1$ belongs to a family of high-affinity $\mathrm{Cu}$ transporters found in a diverse range of organisms from mammals to yeast and plants (for review, see Sharp, 2003). In yeast $\mathrm{Ctr} 1$ is tightly regulated at the transcriptional level by the $\mathrm{Cu}$ content of the local environment (Dancis et al. 1994). However, the mammalian homologues are not regulated following dietary $\mathrm{Cu}$ restriction in rats (Lee et al. 2000) or $\mathrm{Cu}$ loading in human Caco-2 cells (Tennant et al. 2002). Furthermore, endogenous Ctr1 protein expressed at the plasma membrane of Caco- 2 cells (it is unclear whether it is localised to the apical or basolateral membrane) is not modified following exposure to $\mathrm{Cu}$ (Klomp et al. 2002), although there is some evidence, derived from studies on transfected cell lines, for $\mathrm{Cu}$ dependent Ctr1 protein trafficking between the plasma membrane and intracellular compartments (Petris et al. 2003). Interestingly, generation of Ctr1 knock-out mice has revealed that in heterozygous animals (homozygous Ctr1 deletion is lethal) brain and splenic $\mathrm{Cu}$ levels are reduced by at least $50 \%$ whereas gut, liver and kidney $\mathrm{Cu}$ levels are not different from those of wild-type control animals (Kuo et al. 2001; Lee et al. 2001). Taken together, these findings suggest that Ctr1 may not be the major intestinal $\mathrm{Cu}$ transporter, given how tightly absorption is regulated. In addition, there is no evidence for $\mathrm{Cu}-\mathrm{Fe}$ interactions via Ctr1; only Ag, another monovalent metal, competes markedly with $\mathrm{Cu}$ for uptake via this transporter (Lee et al. 2002).

What is the role of DMT1 in intestinal $\mathrm{Cu}$ absorption? Recent work highlights the existence of competition between $\mathrm{Cu}$ and $\mathrm{Fe}$ for transport via DMT1 (Tandy et al 2000; Tennant et al. 2002; Arredondo et al. 2003). Moreover, elegant studies using antisense technology to decrease endogenous DMT1 expression in Caco-2 cells reveal a concomitant decrease in both $\mathrm{Fe}$ and $\mathrm{Cu}$ uptake (Arredondo et al. 2003). If DMT1 is a physiologicallyrelevant $\mathrm{Cu}$ transporter it could be predicted that its expression should be modified by dietary $\mathrm{Cu}$ load. In $\mathrm{Cu}$-deficient rats there is no change in DMT1 expression (Thomas \& Oates, 2003). However, when Caco-2 cells are exposed to high $\mathrm{Cu}$ levels DMT1 protein and mRNA expression are markedly decreased (Tennant et al. 2002). Interestingly, in these studies the effects of $\mathrm{Cu}$ on DMT1 expression are restricted to the Fe-responsive element (IRE)-containing isoforms. This pattern of expression is identical with that observed following treatment of these cells with $\mathrm{Fe}$ (Yamaji et al. 2002), adding weight to the hypothesis that DMT1 is the major intestinal uptake transporter for both $\mathrm{Cu}$ and $\mathrm{Fe}$ and, moreover, suggesting that DMT1 regulation by these metals may occur via a common mechanism. Furthermore, it would appear that the molecular information required for these metal-mediated effects on DMT1 must reside at the level of the IRE in the $3^{\prime}$ untranslated region, since the IRE and non-IRE variants contain the same $5^{\prime}$ promoter region (Lee et al. 1998). Recent data, demonstrating that $\mathrm{Cu}$ (and several other divalent metals) can decrease $\mathrm{Fe}$ regulatory protein-IRE binding, possibly by replacing the labile fourth position $\mathrm{Fe}$ in the $\mathrm{Fe}-\mathrm{S}$ cluster of $\mathrm{Fe}$ regulatory protein 1, support this hypothesis (Oshiro et al. 2002).

Interestingly, in Caco-2 cells treated with $\mathrm{Cu}$ the efflux of $\mathrm{Fe}$ from the cell into the basolateral medium is increased, and this increase is paralleled by an increase in IREG1 protein and mRNA expression (Tennant et al. 2002). Based on these studies it is believed that the following 
coordinate events may occur at the apical and basolateral surfaces of intestinal epithelial cells to permit regulated absorption of $\mathrm{Cu}$ without unduly impairing $\mathrm{Fe}$ transport. At the apical surface there is direct competition between $\mathrm{Cu}$ and Fe for transport via DMT1. Furthermore, when dietary $\mathrm{Cu}$ levels are elevated the expression of the IRE-containing isoform of DMT1 is decreased. The combined effect of these first two stages is to decrease both $\mathrm{Fe}$ and $\mathrm{Cu}$ uptake into the enterocyte. In order not to compromise $\mathrm{Fe}$ status it is believed that basolateral Fe efflux is up regulated. IREG1 levels are increased by exposure of cells to high $\mathrm{Cu}$ (possibly as a result of transcriptional regulation of the gene) leading to increased efflux of Fe from the cell. Importantly, when total transepithelial Fe flux is measured in these studies there is no difference between $\mathrm{Cu}$-treated and control cells, indicating that this basolateral step may be part of a homeostatic mechanism to ensure an adequate supply of $\mathrm{Fe}$ for body metabolism.

\section{Public health issues concerning copper and iron}

The available experimental evidence suggests that there is a close relationship between the metabolic roles of $\mathrm{Cu}$ and $\mathrm{Fe}$ in man (for reviews, see also Fairweather-Tait, 2004; Gambling, 2004). There are clear public health issues associated with imbalances in the nutritional supply of Fe, since Fe-deficiency anaemia is the most common nutritional disorder, affecting up to two billion of the population worldwide. In the UK alone it is estimated that the annual cost to the National Health Service of Fe deficiency is $£ 25 \times 10^{6}$. In contrast, there is little evidence for major health problems associated with dietary $\mathrm{Cu}$ deficiency or overload. Only a few cases of chronic $\mathrm{Cu}$ deficiency have been cited in the literature since the first reported incidence (Cordano et al. 1964). Most recent cases have been associated with chronic malnutrition, and occasionally $\mathrm{Cu}$ deficiency has been seen in infants fed a cow's milk diet (Levy et al. 1985). Dietary $\mathrm{Cu}$ overload is not observed in the general population because of the tightly-regulated relationship between dietary absorption and biliary excretion of excess body $\mathrm{Cu}$. Imbalance in $\mathrm{Cu}$ status is more commonly seen (although the incidence is still rare) in the inborn errors of $\mathrm{Cu}$ metabolism, Menkes disease (an Xlinked recessive disorder that results in body $\mathrm{Cu}$ deficiency and affects one in 200000 live births) and Wilson disease (an autosomal recessive disease with a frequency of between one in 35000 and one in 100000 that leads to $\mathrm{Cu}$ loading of the liver and brain).

More important from a public health perspective are marginal changes in $\mathrm{Cu}$ status. Typical Western diets provide between 0.6 and $1.6 \mathrm{mg} \mathrm{Cu}$ daily (Linder \& Hazeg-Azam, 1996). The UK reference nutrient intake for $\mathrm{Cu}$ is $1.2 \mathrm{mg} / \mathrm{d}$ (Department of Health, 1991), suggesting that in many cases the diet supplies inadequate amounts of $\mathrm{Cu}$ and that marginal $\mathrm{Cu}$ deficiency may be prevalent in the UK population. In light of the plethora of $\mathrm{Cu}$ dependent processes in the body, it is clear that a better understanding of $\mathrm{Cu}$ status is important; however, the assessment of marginal $\mathrm{Cu}$ deficiency remains extremely problematic because of the lack of suitable biomarkers (Milne, 1998). Changes in the most commonly measured variables, i.e. plasma $\mathrm{Cu}$ and caeruloplasmin levels, are only observed in chronic $\mathrm{Cu}$ deficiency, and both can vary independently of status as they are responsive to acutephase infection. It is unclear whether in the general population marginal $\mathrm{Cu}$ deficiency would alter the ferrioxidase activity of caeruloplasmin sufficiently to have a deleterious effect on $\mathrm{Fe}$ mobilisation for utilisation in erythrocyte synthesis. However, in population groups predisposed to the development of Fe deficiency for dietary or other reasons (e.g. teenage females) even a minor reduction in caeruloplasmin activity may be a contributing factor to the progressive development of the Fe-deficient state.

To gain a better understanding of body $\mathrm{Cu}$ status a number of other potential biomarkers have been assessed including $\mathrm{Cu}-\mathrm{Zn}$ superoxide dismutase, whose activity is reduced by severe $\mathrm{Cu}$ restriction but also varies with exercise. In addition, cytochrome c oxidase activity in platelets and leucocytes is relatively sensitive to changes in $\mathrm{Cu}$ status, but the measurements are laborious and not suitable for large epidemiological studies (Milne, 1998). Recent interest has focused on changes in the activity of other $\mathrm{Cu}$-dependent enzymes, including peptidylglycine $\alpha$-amidating mono-oxygenase (Prohaska et al. 1997; Faila, 1999) and plasma diamine oxidase (Kehoe et al. 2000). In addition, it has been suggested that various immune system markers may also act as physiological indicators of marginal $\mathrm{Cu}$ status (Bonham et al. 2002). These 'new' biomarkers require further evaluation, but it is possible that one or more of them may hold the key to unravelling the mysteries of body $\mathrm{Cu}$ status.

Could the relative levels of $\mathrm{Fe}$ and $\mathrm{Cu}$ in the diet contribute to the interactions observed between these two metals? At first glance this type of relationship appears unlikely, since the dietary Fe (approximately $10 \mathrm{mg} / \mathrm{d}$ ) far exceeds $\mathrm{Cu}$ intake $(\leq 1.6 \mathrm{mg} / \mathrm{d})$. However, on close inspection, because $\mathrm{Cu}$ is vastly more bioavailable than $\mathrm{Fe}(70 \%$ for $\mathrm{Cu} v .10 \%$ for $\mathrm{Fe}$ ), absorption of these metals is essentially the same, i.e. $1 \mathrm{mg} / \mathrm{d}$. Given the evidence from cell and molecular studies indicating that $\mathrm{Fe}$ and $\mathrm{Cu}$ employ the same transport mechanism to access enterocytes, i.e. DMT1 (Tennant et al. 2002; Arredondo et al. 2003), it is possible to envisage that increases in the dietary intake of $\mathrm{Fe}$ or $\mathrm{Cu}$, perhaps coupled to the presence or absence of other dietary factors that alter their bioavailability, could have an important impact on the absorption of the other metal.

\section{Conclusions}

It is clear from the experimental evidence available that there is a close relationship between the biology of $\mathrm{Cu}$ and $\mathrm{Fe}$. $\mathrm{Cu}$ deficiency alters body $\mathrm{Fe}$ metabolism via effects on the ferrioxidase activity of caeruloplasmin, a multiCubinding protein that contains $95 \%$ of the $\mathrm{Cu}$ present in the serum, which is essential for Fe release from tissues. A second ferrioxidase, hephaestin, is implicated in Fe efflux from the intestine, although its full role and its regulation in response to changes in $\mathrm{Cu}$ status remain to be fully elucidated. Cellular and molecular data suggest that $\mathrm{Cu}$ and Fe do interact at the intestinal level, possibly through competition for transport into enterocytes via DMT1. 
In addition, emerging evidence indicates that these nutritionally-essential dietary trace metals can regulate a number of key genes involved in intestinal metal absorption, suggesting that the special relationship between $\mathrm{Fe}$ and $\mathrm{Cu}$ may be more intimate than first believed.

\section{Acknowledgement}

The author would like to acknowledge the financial support of the Biotechnology and Biological Sciences Research Council.

\section{References}

Abboud S \& Haile DJ (2000) A novel mammalian iron-regulated protein involved in intracellular iron metabolism. Journal of Biological Chemistry 275, 19906-19912.

Anderson GJ, Murphy TL, Cowley L, Evans BA, Halliday JW \& McLaren GD (1998) Mapping the gene for sex-linked anemia: an inherited defect of intestinal iron absorption in the mouse. Genomics 48, 34-39.

Andrews NC (1999) Disorders of iron metabolism. New England Journal of Medicine 341, 1986-1995.

Andrews NC (2000) Iron homeostasis: insights from genetics and animal models. Nature Reviews Genetics 1, 208-217.

Arredondo M, Munoz P, Mura CV \& Nunez MT (2003) DMT1, a physiologically relevant apical $\mathrm{Cu} 1+$ transporter of intestinal cells. American Journal of Physiology 284, C1525C1530.

Askwith C, Eide D, Van Ho A, Bernard PS, Li L, Davis-Kaplan S, Sipe DM \& Kaplan J (1994) The FET3 gene of S. cerevisiae encodes a multicopper oxidase required for ferrous iron uptake. Cell 76, 403-410.

Attieh ZK, Alaeddine RM, Su T, Anderson GJ \& Vulpe C (2002) Identification of a ferroxidase activity of hephaestin. Journal of Clinical Gastroenterology 34, 370.

Bonham M, O'Connor JM, Hannigan BM \& Strain JJ (2002) The immune system as a physiological indicator of marginal copper status? British Journal of Nutrition 87, 393-403.

Cartwright GE, Gubler CJ, Bush JA \& Wintrobe MM (1956) Studies of copper metabolism. XVII. Further observations on the anemia of copper deficiency in swine. Blood 11, 143-153.

Coppen DE \& Davies NT (1988) Studies on the roles of apotransferrin and caeruloplasmin (EC 1.16.3.1) on iron absorption in copper-deficient rats using an isolated vascularlyand luminally-perfused intestinal preparation. British Journal of Nutrition 60, 361-373.

Cordano A, Baertl JM \& Graham GG (1964) Copper deficiency in infancy. Pediatrics 34, 324-336.

Curzon G \& O'Reilly S (1960) A couple iron-caeruloplasmin oxidation system. Biochemical and Biophysical Research Communications 2, 284-286.

Dancis A, Yuan DS, Haile D, Askwith C, Eide D, Moehle C, Kaplan J \& Klausner RD (1994) Molecular characterization of a copper transport protein in $S$. cerevisiae: an unexpected role for copper in iron transport. Cell 76, 393-402.

Department of Health (1991) Dietary Reference Values for Food Energy and Nutrients for the United Kingdom. Report on Health and Social Subjects no. 41. London: H. M. Stationery Office.

Donovan A, Brownlie A, Zhou Y, Shepard J, Pratt SJ, Moynihan $\mathrm{J}$, et al. (2000) Positional cloning of zebrafish ferroportin1 identifies a conserved vertebrate iron exporter. Nature $\mathbf{4 0 3}$, 777-781.

Faila M (1999) Considerations for determining 'optimal nutrition' for copper, zinc, manganese and molybdenum. Proceedings of the Nutrition Society 58, 497-505.

Fairweather-Tait SJ (2004) Iron nutrition in the UK: getting the balance right. Proceedings of the Nutrition Society $\mathbf{6 3}$ 519-528.

Fleming MD, Trenor CC, Su MA, Foernzler D, Beier DR, Dietrich WF \& Andrews NC (1997) Microcytic anaemia mice have a mutation in Nramp2, a candidate iron transporter gene. Nature Genetics 16, 383-386.

Fox PL (2003) The copper-iron chronicles: The story of an intimate relationship. BioMetals 16, 9-40.

Frazer DM, Vulpe CD, McKie AT, Wilkins SJ, Trinder D, Cleghorn GJ \& Anderson GJ (2001) Cloning and gastrointestinal expression of rat hephaestin: relationship to other iron transport proteins. American Journal of Physiology 281, G931-G939.

Gambling L \& McArdle HJ (2004) Iron, copper and fetal development. Proceedings of the Nutrition Society $\mathbf{6 3}$, 553-562.

Gunshin H, Mackenzie B, Berger UV, Gunshin Y, Romero MF, Boron WF, Nussberger S, Gollan JL \& Hediger MA (1997) Cloning and characterization of a mammalian proton-coupled metal-ion transporter. Nature 388, 482-487.

Hallberg L (1981) Bioavailability of dietary iron in man. Annual Review of Nutrition 1, 123-147.

Harris ZL, Durley AP, Man TK \& Gitlin JD (1999) Targeted gene disruption reveals an essential role for ceruloplasmin in cellular iron efflux. Proceedings of the National Academy of Sciences USA 96, 10812-10817.

Harris ZL, Klomp LW \& Gitlin JD (1998) Aceruloplasminemia: an inherited neurodegenerative disease with impairment of iron homeostasis. American Journal of Clinical Nutrition 67, 972S-977S.

Hart EB, Steenbock H, Waddell J \& Elvehjem CA (1928) Iron in nutrition. VII. Copper as a supplement to iron for hemoglobin building in the rat. Journal of Biological Chemistry 77, 797-812.

Holmberg CG \& Laurell C-B (1948) Investigations in serum copper. II. Isolation of the copper containing protein and a description of some of its properties. Acta Chemica Scandinavia 2, 550-556.

Kehoe CA, Turley E, Bonham MP, O'Connor JM, McKeown A, Faughnan MS, Coulter JS, Gilmore WS, Howard AN \& Strain JJ (2000) Response of putative indices of copper status to copper supplementation in human subjects. British Journal of Nutrition 84, 151-156.

Klomp AE, Tops BB, Van Denberg IE, Berger R \& Klomp LW (2002) Biochemical characterization and subcellular localization of human copper transporter 1 (hCTR1). Biochemical Journal 364, 497-505.

Knopfel M \& Solioz M (2002) Characterization of a cytochrome b(558) ferric/cupric reductase from rabbit duodenal brush border membranes. Biochemical and Biophysical Research Communications 291, 220-225.

Kuo YM, Zhou B, Cosco D \& Gitschier J (2001) The copper transporter CTR1 provides an essential function in mammalian embryonic development. Proceedings of the National Academy of Sciences USA 98, 6836-6841.

Lee GR, Nacht S, Lukens JN \& Cartwright GE (1968) Iron metabolism in copper-deficient swine. Journal of Clinical Investigation 47, 2058-2069.

Lee J, Peña MM, Nose Y \& Thiele DJ (2002) Biochemical characterization of the human copper transporter Ctr1. Journal of Biological Chemistry 277, 4380-4387. 
Lee J, Prohaska JR, Dagenais SL, Glover TW \& Thiele DJ (2000) Isolation of a murine copper transporter gene, tissue specific expression and functional complementation of a yeast copper transport mutant. Gene 254, 87-96.

Lee J, Prohaska JR \& Thiele DJ (2001) Essential role for mammalian copper transporter Ctr1 in copper homeostasis and embryonic development. Proceedings of the National Academy of Sciences USA 98, 6842-6847.

Lee PL, Gelbart T, West C, Halloran C \& Beutler E (1998) The human Nramp2 gene: characterization of the gene structure, alternative splicing, promoter region and polymorphisms. Blood Cells and Molecular Diseases 24, 199-215.

Levy Y, Zeharia A, Grunebaum M, Nitzan M \& Steinherz R (1985) Copper deficiency in infants fed cow milk. Journal of Pediatrics 106, 786-788.

Linder MC \& Hazegh-Azam M (1996) Copper biochemistry and molecular biology. American Journal of Clinical Nutrition 63, 797S-811S.

Linder MC, Zerounian NR, Moriya M \& Malpe R (2003) Iron and copper homeostasis and intestinal absorption using the Caco2 cell model. BioMetals 16, 145-160.

McKie AT, Barrow D, Latunde-Dada GO, Rolfs A, Sager G, Mudaly E et al. (2001) An iron-regulated ferric reductase associated with the absorption of dietary iron. Science 291, 1755-1759.

McKie AT, Marciani P, Rolfs A, Brennan K, Wehr K, Barrow D et al. (2000) A novel duodenal iron-regulated transporter, IREG1, implicated in the basolateral transfer of iron to the circulation. Molecular Cell 5, 299-309.

Mercer JFB (2001) The molecular basis of copper-transport diseases. Trends in Molecular Medicine 7, 64-69.

Milne DB (1998) Copper intake and assessment of copper status. American Journal of Clinical Nutrition 67, 1041S-1045S.

Miyajima H, Nishimura Y, Mizoguchi K, Sakamoto M, Shimizu $\mathrm{T}$ \& Honda N (1987) Familial apoceruloplasmin deficiency associated with blepharospasm and retinal degeneration. Neurology 37, 761-767.

Osaki S \& Johnson DA (1969) Mobilization of liver iron by ferroxidase (ceruloplasmin). Journal of Biological Chemistry 244, 5757-5758.

Osaki S, Johnson DA \& Frieden E (1966) The possible significance of the ferrous oxidase activity of ceruloplasmin in normal human serum. Journal of Biological Chemistry 241, 2746-2751.

Oshiro S, Nozawa K, Hori M, Zhang C, Hashimoto Y, Kitajima S \& Kawamura K (2002) Modulation of iron regulatory protein-1 by various metals. Biochemical and Biophysical Research Communications 290, 213-218.

Peña MO, Lee J \& Thiele DJ (1999) A delicate balance: Homeostatic control of copper uptake and distribution. Journal of Nutrition 129, 1251-1260.

Petris MJ, Smith K, Lee J \& Thiele DJ (2003) Copper-stimulated endocytosis and degradation of the human copper transporter, hCtr1. Journal of Biological Chemistry 278, 9639-9646.

Prohaska JR, Tamura T, Percy AK \& Turnlund JR (1997) In vitro copper stimulation of plasma peptidylglycine alpha-amidating monooxygenase in Menkes disease variant with occipital horns. Pediatrics Research 42, 862-865.
Puig S \& Thiele DJ (2002) Molecular mechanisms of copper uptake and distribution. Current Opinions in Chemical Biology 6, $171-180$

Rolfs A, Bonkovsky HL, Kohlroser JG, McNeal K, Sharma A, Berger UV \& Hediger MA (2002) Intestinal expression of genes involved in iron absorption in humans. American Journal of Physiology 282, G598-G607.

Sharp PA (2003) Ctr1 and its role in body copper homeostasis. International Journal of Biochemistry and Cell Biology $\mathbf{3 5}$ 288-291.

Smith SE \& Medlicott M (1944) The blood picture of iron and copper deficiency anemias in the rat. American Journal of Physiology 141, 354-358.

Syed BA, Beaumont NJ, Patel A, Naylor CE, Bayele HK, Joannou CL, Rowe PS, Evans RW \& Srai SK (2002) Analysis of the human hephaestin gene and protein: comparative modelling of the N-terminus ecto-domain based upon ceruloplasmin. Protein Engineering 15, 205-214.

Tandy S, Williams M, Leggett A, Lopez-Jimenez M, Dedes M, Ramesh B, Srai SK \& Sharp P (2000) Nramp2 expression is associated with $\mathrm{pH}$-dependent iron uptake across the apical membrane of human intestinal Caco-2 cells. Journal of Biological Chemistry 275, 1023-1029.

Tennant J, Stansfield M, Yamaji S, Srai SK \& Sharp P (2002) Effects of copper on the expression of metal transporters in human intestinal Caco-2 cells. FEBS Letters 527, 239-244.

Tennant JP, Jai T \& Sharp PA (2004) Mechanisms involved in copper uptake by human intestinal epithelial cells. Proceedings of the Nutrition Society 63, 35A.

Thomas C \& Oates PS (2003) Copper deficiency increases iron absorption in the rat. American Journal of Physiology 285, G789-G795.

Trinder D, Oates PS, Thomas C, Sadleir J \& Morgan EH (2000) Localisation of divalent metal transporter 1 (DMT1) to the microvillus membrane of rat duodenal enterocytes in iron deficiency, but to hepatocytes in iron overload. Gut 46, 270-276.

Turnlund JR, Keyes WR, Anderson HL \& Acord LL (1989) Copper absorption and retention in young men at three levels of dietary copper by use of the stable isotope ${ }^{65} \mathrm{Cu}$. American Journal of Clinical Nutrition 49, 870-878.

Turnlund JR, Keyes WR, Peiffer GL \& Scott KC (1998) Copper absorption, excretion, and retention by young men consuming low dietary copper determined by using the stable isotope ${ }^{65} \mathrm{Cu}$. American Journal of Clinical Nutrition 67, $1219-1225$.

Vulpe CD, Kuo YM, Murphy TL, Cowley L, Askwith C, Libina N, Gitschier J \& Anderson GJ (1999) Hephaestin, a ceruloplasmin homologue implicated in intestinal iron transport, is defective in the sla mouse. Nature Genetics 21, 195-199.

Yamaji S, Tennant J, Sharp P \& Srai SKS (2002) Differential regulation of divalent metal transporter (DMT1) splice variant expression by non-haem iron in human intestinal Caco- 2 cells. Journal of Physiology, London 539, 20P.

Zerounian NR \& Linder MC (2002) Effects of copper and ceruloplasmin on iron transport in the Caco 2 cell intestinal model. Journal of Nutritional Biochemistry 13, 138-148. 
https://doi.org/10.1079/PNS2004386 Published online by Cambridge University Press 